\title{
Rethinking corporate social responsibility in the age of climate change: a communication perspective
}

\author{
Myria W. Allen ${ }^{1 *}$ and Christopher A. Craig ${ }^{2}$
}

\begin{abstract}
In the winter of 2015 world leaders presented plans for keeping the global temperature rise below $2{ }^{\circ} \mathrm{C}$ due to projected climate change threats. These threats present organizations, communities, and citizens with the need to change viewing corporate social responsibility (CSR) as a voluntary luxury to being a necessity. This essay proposes refocusing CSR efforts in light of projected climate challenges and expanding our investigation into the role of communication in such efforts. Communication is more than a tool to craft a positive corporate image so as to gain or protect legitimacy. It is the means through which CSR sustainability-related initiatives are created and disseminated within organizations and among their key stakeholders (i.e., governments, communities, competitors, supply chains, employees). Suggestions for future research exploring CSR, sustainability, and communication are offered.
\end{abstract}

Keywords: Climate change, Corporate social responsibility, Sustainability, Corporate communication

\section{Background}

In 2015, working with the World Economic Forum, the CEOs of 43 companies operating in over 150 countries and territories representing 20 economic sectors signed an open letter to world leaders urging for concrete climate action (Open letter 2015). Together these companies generated over $\$ 1.2$ trillion in revenue in 2014. In the letter they wrote,

We agree on the need for inspirational and meaningful global action and aligned messaging. We will act as ambassadors for climate action, focusing on solutions and economic opportunities and using "the science debate is over: climate change is real and addressable" as one of the common themes to raise public awareness. We will actively manage climate risks and incorporate them in decision making - not least to realize growth opportunities. We will take steps to implement effective strategies to strengthen not only our companies' but also societal resilience.

\footnotetext{
*Correspondence: myria@uark.edu

'Department of Communication, University of Arkansas, 434 Kimpel Hall, Fayetteville, AR 72701, USA

Full list of author information is available at the end of the article
}

Climate change challenges present organizations (e.g., companies, corporations, nongovernmental organizations (NGOs)), communities, and citizens with the need to redefine current views on corporate social responsibility (CSR) from a voluntary luxury as being a necessity. By midcentury, climate challenges are expected to seriously disrupt business-as-usual and change the way citizens live their lives around the world. Indeed, many countries are already experiencing the vanguard of challenges and many organizations are planning for the projected risks they will face (e.g., limited clean water, expensive and unreliable energy). This essay proposes refocusing CSR efforts in light of projected climate challenges and expanding our investigation into the role of communication in such efforts. Communication is more than a tool to craft a positive corporate image so as to gain or protect legitimacy. It is the means through which CSR sustainability-related initiatives are created and disseminated within organizations and among their key stakeholders (i.e., governments, communities, competitors, supply chains, employees).

In the following pages, projected climate change challenges are identified and the Paris 2015 response discussed, literature defining CSR, responsibility, and sustainability is 
reviewed, a brief history of CSR in the United States (U.S.) is provided, the need to study CSR globally is addressed, the role of communication is described, and some research agendas are offered to guide future scholarship appearing in the International Journal of Corporate Social Responsibility.

\section{Climate change challenges}

This essay focuses on CSR issues related to climate change and the corporate turn toward sustainability. The Intergovernmental Panel on Climate Change (IPCC 2013) released a report entitled Climate Change 2013: The Physical Science Basis. The report describes the very high probability by the late 21st century of increased temperatures and more heat waves over most land areas; increased frequency, intensity, and/or amount of heavy precipitation; increased intensity and duration of drought; increased intense tropical cyclone activity; and increased extreme high sea level. In terms of water, the World Resources Institute (2015) provides their Aqueduct map of global water risks, and rising sea levels are expected to contaminate coastal freshwater reserves, increase flooding risks, and displace large coastal populations. In 2010 almost $40 \%$ of the U.S. population lived in counties on the shoreline. In terms of food production, warmer temperatures threaten food production requiring plants to use more water while encouraging more insects to proliferate leading to higher occurrence rates of vectorborne disease (IPCC 2014). Food costs and scarcity are projected to increase. Globally, climate is expected to increase the possibility of war (Department of Defense 2014), and the lack of food and/or water to migrating populations has been linked to recruitment by terrorist organizations.

Global climate change presents the most pressing issues for industry, government, and civil society this century (Okereke et al. 2012), and forecasts for the middle and the end of this century just in the U.S. are chilling (see National Climate Assessment 2014). Related environmental metatrends (i.e., decreased freshwater access and global climate change) are threatening to disrupt organizational operations due to reduced resource supply (e.g., inadequate water) and the potential for a displaced workforce and customer base (Shen et al. 2011; Wei and Fang 2012). Climate change is expected to increase healthcare costs, disrupt access to and lead to higher costs for supply chain materials, and change tax structures as the public sector attempts to cope with intensified weather and climate conditions which challenge their ability to provide infrastructure and social-service support (Allen 2016). Climate change challenges increase risks to insurers and insurance costs for organizations and individuals (Tucker 1997; Wei and Fang 2012). For example, between 1980 and 2014 organizations, individuals, and governments in the Southeastern U.S. collectively experienced more billion dollar disasters related to extreme weather events than elsewhere in the U.S. (National Oceanic and Atmospheric Administration 2015) and increased extreme events and climatic variability are projected to increase (Ingram et al. 2013). By 2050 the economic impact of extreme events and climatic variability is projected to increase financial losses by factors up to 3.9 times those currently experienced (Preston 2013). This further increases the necessity that organizational actors act now to mitigate climate changes and to avoid risks related to the changes.

Climate change has been linked to carbon emissions and reliance on fossil fuels is the primary driver of the increase in carbon. Between 1854 and 2010, the majority of carbon emissions negatively influencing rising temperatures globally are attributable to large energy producing organizations (Heede 2014; IPCC 2014). Climate change has also been positively linked to electricity consumption, and electricity consumption is projected to increase along with changing climatic variability and extreme weather events (Craig 2016; McFarland et al. 2015). As fossil fuels are used to generate electricity for organizational and individual consumers, carbon emissions are released and trapped in the Earth's atmosphere. When working correctly solar radiation from the sun passes through our atmosphere, some is trapped but most reflects back into space. Increasingly, the buildup of carbon trapped in our atmosphere hinders the ability of solar radiation to reflect off Earth surfaces and exit out of our atmosphere. This change effectively allows heat in but diminishes its ability to exit. The system is further complicated by the melting of more reflective ice, allowing for additional heat to be absorbed in the world's oceans and less solar radiation to be reflected (United Nations Environmental Programme 2013). The world's scientists have been warning the consequences for humanity can be very dangerous if we do not keep the global temperature rise below $2{ }^{\circ} \mathrm{C}$.

\section{The changing global conversation}

Awareness of impending climate change challenges and the need to limit our use of fossil fuels and other forms of carbon emissions were discussed in 2009 at the United Nations Conference on Climate Change in Copenhagen. These discussions set the scene for a historic meeting in Paris in the winter of 2015 (i.e., COP 21). Prior to December 12, 2015, 186 countries published action plans for how they intend to reduce their greenhouse gas (GHG) emissions. "This agreement marks a change in direction, towards a new world. It confirms the target of keeping the rise in temperature below $2{ }^{\circ} \mathrm{C}$...The agreement even establishes, for the first time, that we should be aiming for $1.5{ }^{\circ} \mathrm{C}$, to protect island states, which are the most threatened by the rise in sea levels" (United Nations Conference on Climate Change 2015a). The agreement opened for signing by the countries on April 22 in New York. It only goes into effect if ratified by 55 countries, representing at least $55 \%$ of emissions. An evaluation of 
the proposed action plans indicates that even with those changes the rate of global warming would be between $2.7^{\circ} \mathrm{C}$ and $3{ }^{\circ} \mathrm{C}$, still above the threshold recommended by scientists (United Nations Conference on Climate Change 2015b). Following the agreement, social media carried many enthusiastic comments generated by world leaders (United Nations Conference on Climate Change 2015c). Jim Yong Kim, $12^{\text {th }}$ president of the World Bank Group, commented "People rarely change the world when they work within the constraints of what they think is possible-the ambition of \#COP21 is truly historic." Tony de Brum, Minister of Foreign Affairs of the Republic of the Marshall Islands, commented "We have made history today. With this agreement I can go back home to my people and say we now have a pathway to survival". Narendra Modi, Prime Minister of India, commented the "Outcome of \#ParisAgreement has no winners or losers. Climate justice has won \& we are all working towards a greener future." However, Margot Wallström, Minister of Foreign Affairs of Sweden, wrote, "Felicitations! A global deal on climate change is an enormous achievement. But remember: A deal is only as good as its implementation".

Moving forward in the face of the threats posed by climate change, national governments are not the only actors. Our global response requires a renewed commitment of organizational actors to engage in meaningful sustainability and corporate responsiveness initiatives. Historically corporate actors (both large and small) have been a major cause of the problem. Recent evidence surfaced that Exxon knew of climate change in 1981 but funded deniers for 27 more years (Goldenberg 2015) while reporting on a wide variety of CSR-related activities, and there were certainly other corporate actors which have displayed a blatant disregard for anything beyond profit maximization and resource exploitation. However, increasingly businesses are recognizing the need to limit their carbon emissions and other natural resource use (e.g., water). In 2013 more than 500 businesses, including giants like General Motors, Nike, Starbucks, Levi Strauss, and Unilever, signed a Climate Declaration that urged U.S. policymakers to capture economic opportunities associated with addressing climate change (BICEP 2013). A variety of other initiatives exist to enlist companies in the fight against climate change including the Global Compact's Caring for Climate, the World Wildlife Federation's Climate Savers, and the Climate Group's RE100 initiative, part of the World Economic Forum. At COP 21 nonstate actors signed the Paris Pledge for Action (The pledge 2015) which reads,

As cities, regions, businesses, investors, civil society groups, trade unions and other signatories, coming from every sector of society and every corner of the world, we realize that dangerous climate change threatens our ability and the ability of future generations to live and thrive in a peaceful and prosperous world. We also realize that taking strong action to reduce emissions can not only reduce the risks of climate change but also deliver better growth and sustainable development.

For-profit organizations are not the only ones taking action. Cities are joining the International Council for Local Environmental Initiatives (ICLEI) which is the world's leading network of over 1000 cities, towns and metropolises committed to building a sustainable future; universities are signing the American College and University Presidents' Climate Commitment; and sports teams are joining the Green Sports Alliance (Allen 2016) as organizations of all types commit to changing the ways they run their operations and do business.

Now that some climate change challenges and organizational responses have been discussed, the focus shifts to CSR. It is important to have a better understanding of what CSR is and how it differs from organizational efforts surrounding sustainability. CSR efforts should be part of an organization's response to climate change challenges but are an insufficient response if not part of a larger coordinated corporate and industry effort. Today with our unfolding understanding of the impending impact of climate change on our species' survival, "Important initiatives are afoot within and outside corporate boundaries to .... broaden relationships between corporations and their multiple stakeholders, to apply consumer pressure toward social responsiveness ... and to convert what sometimes begin as the mere window dressings of corporate philanthropy and nods to community projects into meaningful and sustained efforts" (Cheney et al. 2007, p. 3).

\section{Key concepts defined: responsibility, CSR, sustainability}

What is corporate social responsibility? CSR is a well-known and widely used term in business, government, NGOs, and academia, but there is little agreement about what it means and what it entails (Brei and Böhm 2013). Yet scholars representing multiple academic disciplines (e.g., organizational and management studies, communication and marketing studies, international relations, political theory) are researching and writing about the topic. Buchholtz and Carroll (2008) write that CSR requires that business organizations encompass "the economic, legal, ethical, and discretionary (philanthropic) expectations that society has of organizations at a given point in time" (p. 40). It is often used as an umbrella term that encompasses a range of ethical discourses and practices including business ethics, corporate philanthropy, and corporate citizenship. In these discussions, CSR generally involves discretionary organizational actions which means they are often sporadic, short-term, idiosyncratic (Brei and Böhm 2013), and loosely coupled with other organizational actions and actors. When allowed to select what social problems to focus on 
corporations will support a very narrow set of social needs and values (Shumate and O'Connor 2010) - those which ultimately will benefit the corporation. Depending on an organization's products and operations, the legal frameworks in the countries where they operate, and the strength of various civil society institutions different issues become the focus of their CSR efforts.

To better understand CSR we investigate the definition of responsibility. Responsibility is one of the three key words in CSR. Responsibility is the state, quality, or fact of being responsible. Responsible includes being legally or ethically accountable for the care or welfare of another, personally accountable or having the ability to act without guidance or superior authority, capable of making moral or rational decisions on one's own and therefore answerable for one's behavior, capable of being trusted or depended upon, characterized by good judgment or sound thinking, having the means to fulfill obligations, required to be answerable (American Heritage Dictionary 1982). We italicize key words in this definition most important to our understanding of CSR. Words like legal or ethically accountable, welfare of another, personal accountability, acting without guidance, rational decision-making, good judgement, and trust place the faith to take action in the hands of individual corporate actors often guided by their own self-interests and operating in changing legal and normative environments. We argue that CSR as practiced by many, but certainly not all, organizations is only loosely related to the word 'responsible'.

So CSR often is addressed through voluntary responses to an issue perceived to have ethical components. But it is difficult to identify what ethical obligations exist at a particular time and place. Some argue that corporate actors' fiduciary duty to their stockholders is a moral responsibility. However, increasingly armed with the knowledge of impending climate change challenges key spokespeople for various faith communities are talking about the corporate actors' moral responsibilities to act in humanity's best interests, and taking action themselves. For example, in his encyclical letter, Pope Francis (2014) wrote, "Many of those who possess more resources and economic or political power seem mostly to be concerned with masking the problems or concealing their symptoms" (sect. 26), "A true 'ecological debt' exists, particularly between the global north and south, connected to commercial imbalances with effects on the environment, and the disproportionate use of natural resources by certain countries over long periods of time" (sect. 51), "Economic powers continue to justify the current global system where priority tends to be given to speculation and the pursuit of financial gain, which fail to take the context into account, let alone the effects on human dignity and the natural environment. Here we see how environmental deterioration and human and ethical degradation are closely linked" (sect. 56). Other religious groups are speaking out. For example, The World Council of Churches and the Church of England Pensions Board signed the Paris Pledge (The pledge 2015). In terms of action, The Episcopal Church became the third and largest faith group in the U.S. to vote to divest from fossil fuel holdings so as to be more consistent with moral beliefs (Eisenstadter 2015).

What is sustainability? Although related, sustainability initiatives should not be conflated with CSR. The most frequently used definition of sustainability appearing in the scholarly literature focusing on organizations reads, "Sustainable development is development that meets the needs of the present without compromising the ability of future generations to meet their own needs" (World Commission on Environment and Development 1987, p. 43). At its core sustainability is concerned with resource use consistent with the carrying capacity of our planet so as to maintain human life. Elkington (1999) linked corporate sustainability with the idea of the triple bottom line profits, planets and people. An organization's economic, social, and environmental performance are interconnected. The economic dimension centers on the value creation and enhanced financial performance of an organization's sustainability-related activities. The social dimension encourages organizations to consider their impact on society and addresses issues such as community relations, support for education, and charitable contributions. The environmental dimension involves activities that do not erode natural resources due to prudent corporate environmental management efforts (Allen 2016). Of these three dimensions the social dimension, often constrained by the economic dimension, is most closely related to the issues commonly associated with CSR.

Today, sustainability is seen by many to be an attractive, if not necessary, development in how businesses operate. The main argument is there can be a positive relationship between environmental, social, and financial performance. Blackburn (2007) provides seven business case arguments including increased reputation and brand strength; more competitive, effective, and desirable products and services; new markets; productivity; lessened operational burdens and interference; lower supply chain costs; lower cost of capital; and less legal liability. In their review of related theories, research, and tools, Salzmann et al. (2005) conclude that the research does not show a strong causal relationship between the variables. However, a lack of unified findings is not surprising since an organization's performance depends on various organizational dynamics, its industry sector, the magnitude and types of environmental challenges faced, and the tools used to measure environmental, social and financial performance (Allen 2016). 
The idea of sustainability extends CSR by focusing organizations and researchers on the need to equitably balance environmental and social concerns with economic concerns - a balance rarely really existing in CSR discussions which continue to privilege economic concerns, and to a much lesser extent social concerns. This privileging of economic concerns is evident in how Carroll (1991) described CSR's four segments. A business must pursue maximum profitability as an economic responsibility, be aware of and comply with all laws and regulations, operate in a way that respects the concerns and values of society at large -and adjust to new values and concerns, and support educational, religious, artistic, medical, social welfare, or other charitable endeavors in order to meet its philanthropic responsibilities. Critics argue that CSR often attempts to mask and silence historical struggles within communities and countries. Rather than helping deal with the social, environmental, and economic issues, CSR campaigns can actually blur the lines of accountability and responsibility between public and private actors (Brei and Böhm 2013).

\section{A brief history of CSR and sustainability}

In the U. S. what came to be called CSR emerged post World War II during a time of postwar prosperity, although its roots can be traced back to the dawn of the Industrial Revolution. According to Cheney et al. (2007) some scholars credit the idea of CSR to economics professor Howard R. Bowen who talked about the emergence of a new set of expectations for corporations in his book Social Responsibilities of the Businessman (1953). Several years later the iron law of responsibility emerged which argued that businesses' responsibility should be commensurate with their social power. Expectations regarding corporate philanthropy (i.e., the effort or inclination to increase the well-being of mankind, as by charitable aid or donations) emerged along with new governmental regulations, major regulatory agencies, and the birth of some strong public interest groups.

In the 1970s societal expectations shifted to ask what companies could do to better the world beyond merely ensuring their own survival. The 1970s was a period when multiple landmark environmental laws were passed in the U.S. (Cox 2013) which required polluting companies to take responsibility for some of the previously externalized consequences of their operations. In response to societal pressures and regulatory threats corporate actors began engaging in even more corporate political action, public affairs, lobbying, and public relations efforts. These efforts were focused on managing the public's normative expectations for corporate actors. Organizations began deciding how to act (or not) around issues such as resource degradation, pollution, carbon emissions, and climate change. How an organization positions itself strategically around such issues can influence that organization's legitimacy in the eyes of society and its key stakeholders. Legitimacy is "a generalized perception or assumption that the actions of an entity are desirable, proper, or appropriate within some socially constructed system of norms, values, beliefs, and definitions" (Suchman 1995, p. 574). A legitimacy gap (Sethi 1979) exists when society expects something from an organization that it cannot or will not deliver, and this can present a threat for the organization (e.g., a loss in clients, customers, or donors; government sanctions; citizen protests; difficulty attracting employees). The quest to be perceived as a legitimate corporate actor remains a driving force behind CSR and sustainability efforts (Allen 2016).

In 1970 Milton Friedman's now classic essay appeared to a receptive business community. Friedman argued that the social responsibility of business is to increase its profits and that decisions regarding the allocation of scarce resources should be made by political, not market, mechanisms (Cheney et al. 2007). Friedman felt if businesses make decisions based on shareholder value then all would benefit. This became the neoliberal philosophy enacted through the trickle-down economics orientation which gained strength during the Reagan era and remains a dominant Discourse in the U.S. today. Discourses reflect the general and enduring systems of thought which, in turn, influence the formation and expression of ideas within a historically situated time (Grant et al. 2004). Friedman argued that a focus on social responsibility is "a fundamentally subversive doctrine" in a free society (as cited in Cheney et al. 2007, p. 6). Others argued that profit-making organizations have no legitimate interest in philanthropy and to do so distracts from their primary obligation of making a profit (Seeger and Hipfel 2007). The argument goes that profit-making organizations simply do not have the resources needed to solve social problems. Social problems should be solved by government and social welfare organizations. However, government's capacity and commitment to do so has diminished over time. In the 1980s government power to regulate economies was replaced by a more laissez fair, free market, neoliberal economy (Cheney et al. 2007). By the late 1980s the negative social effects of neoliberalism began emerging. Unemployment rose, the wealth gap widened dramatically, jobs moved overseas, the financial industry deregulated, and environmental degradation increased in the U.S. as businesses sought profit.

During the 1990s discussions of CSR expectations and offerings intensified as the corporate sector became the primary societal institution influencing social developments. Simultaneously, institutions more traditionally associated with the social good weakened (e.g., governments, religious, familial, educational, and community) 
(McMillan 2007). "Pursuing a narrow mission (i.e., shareholder profit) and without the influence of countervailing institutions, such as churches, small businesses, strong local civic organizations, and schools, the modern organization has also assumed the oversight of social responsibility" (p. 17). Some scholars see the emergence of CSR as part of a broader historical shift from government to governance which involves a new political role for corporations, often in cooperation with NGOs, where global social problems (e.g., poverty and health issues) previously seen as government's responsibilities (Brei and Böhm 2013) are addressed.

Today, CSR can be categorized into two streams (Brei and Böhm 2013), or contrasting perspectives (Dhanesh 2015]. Some scholars and institutions such as the World Business Council for Sustainable Development (WBCSD) see CSR as a way to fulfill businesses' commitment to economic development while simultaneously improving the quality of life of the workforce, their families, the community, and society at large (Brei and Böhm 2013). From this perspective wider societal aims for development and human well-being are part of the CSR agenda. The second stream of CSR is more focused on the strategic implications of CSR for corporations and less on its effects for society. An organization's financial performance is dependent on successful cooperation with stakeholders and shareholders (i.e., stakeholder management). Corporations are more likely to conduct and discuss CSR projects associated with economic benefits. In the last two decades, corporate involvement in aid and development projects emerged as a powerful corporate discourse because CSR could contribute to profits. Dhanesh (2015) talks about the two contrasting perspectives as involving the moral and the strategic. The moral perspective suggests that businesses engage in socially responsible behaviors because it is "the right thing to do" or they are motivated by intrinsic factors (e.g., ethical values and moral leadership). The strategic perspective suggests that businesses engage in CSR because of extrinsic motivators (e.g., market and institutional pressures) and expected benefits (e.g., profits, increased employee commitment, customer loyalty). A third perspective of CSR combines the two. Given the impending climate challenges being forecast globally it is likely that this third perspective will be the strongest impetus for CSR moving forward.

In terms of sustainability, following the Rio de Janeiro Earth Summit of 1992, the WBCSD, which included 162 of the world's largest corporations, primarily represented by the manufacturing, mining and energy sectors, coauthored Changing Course: A Global Business Perspective on Development and the Environment, along with Stephan Schmidheiny (1992). In 2002, at the World Summit on Sustainable Development, the corporate leaders present articulated that business must be a major participant in sustainable development. Interest in sustainability have grown over the past decade (McIntosh 2007). "Multistakeholder engagement among business, government, and civil society, have resulted in a significant number of global voluntary corporate citizenship initiatives" (p. 46). Allen (2016) discusses many of these in terms of their importance to environmental sustainability including the Global Reporting Initiative (environmental reporting), the Carbon Disclosure Project (environmental reporting directed to the investment community), ethical workplace management systems certifications (SA8000), and sustainability management systems assurance (AA1000S). Some argue such voluntary mechanisms are replacing or preventing regulatory initiatives and therefore setting back real corporate responsibility (see McIntosh 2007). However, compliance with voluntary reporting guidelines and certification programs, along with legal changes, are beginning to change the normative environment of how businesses conduct themselves in terms of their environmental and social obligations. Also, such initiatives provide organizations with new metrics that can be utilized to bring about corrective actions.

CSR activities and sustainability initiatives are not without critics. There is a growing literature that critically addresses CSR practices and discourses (see Brei and Böhm 2013). Critics argue that short-term CSR actions are ineffective if not dangerous. Cause-related marketing campaigns often associated with CSR efforts allow organizations to make a profit due to global social problems (i.e., limited safe drinking water) especially in developing countries. CSR can function as a depoliticizing marketing practice that cements the role and power of corporate actors without delivering real improvements to people and communities. Critics argue that CSR is increasingly part of the problem, that halfhearted CSR campaigns are not effective, that CSR is just another management fad that supports wider corporate and capitalist ideologies, that CSR can have a devastating impact on workers, local communities and other stakeholders, and that modern CSR scholarship is irrelevant because it fails to articulate a realistic normative position or adequately study its subject. However, it is important to distinguish isolated CSR cause-related marketing campaigns from the more systematic and widespread changes occurring within the business communities as sustainability-related initiatives (e.g., carbon reporting, ethical workplace management systems certifications, sustainability management systems assurances) take hold. See Allen (2016) for a review of the major criticisms surrounding sustainability initiatives.

\section{CSR as a global topic}

The CSR tradition developed differently in other parts of the world (Cheney et al. 2007). In Europe social-democratic 
practices provided for a greater regulatory role for governments and corporations were expected to respond to social needs and demands. Governments and trade unions collaborated to exert social control over corporate actions in the publics' interest. The ecological modernization Discourse is stronger than in the U.S. where the sustainability Discourse predominates (Allen 2016). Distinctive models also developed in Japan and China. Dhanesh (2015) describes the key drivers of CSR in India. He argues that the practice of CSR is embedded within specific sociocultural contexts which means that CSR needs to be studied in situ. Currently little is known about CSR in emerging economies, and even less about specific sociocultural practices and traditions that drive CSR. However, research suggests that CSR is influenced by Confucianism in East Asia, by Kyosei in Japan, and by dharma in India.

Stohl et al. (2007) discuss the new generation of global CSR brought on by four previously identified dynamic processes of globalization: no distinction between 'out there' and 'in here'; 'glocalization' in new and old media forms; the complex network of organizational relations across sectors; and the permeability of public/private boundaries. We would add that the challenges brought on by global climate change add a new process that brings a critical new dimension to our need for serious discussions regarding global CSR.

Given the International Journal of Corporate Social Responsibility's aims as the journal develops we will learn more about these alternative histories, models, and drivers of CSR across the globe. Recent CSR scholarship is emerging from Scandinavia (e.g., Morsing et al. 2007), Asia (e.g., Whelan 2007), Singapore (e.g., Sriramesh et al. 2007), Mexico (e.g., Chavarria 2007), New Zealand (e.g., Lawrence 2007), and South Africa (e.g., Samkin and Lawrence 2007). Recent articles appearing in communication journals which focus on CSR have investigated informational technology companies in India (Chaudhri and Wang 2007); corporate websites (Tang et al. 2015), media discourse (Tang 2012), and social media (Yin et al. 2015) as they relate to CSR in China; CSR in Romania (White et al. 2011); CSR campaigns in Turkey (ÖztÜrk 2012); health literacy as an example of CSR in Europe (Sørensen and Brand 2011); ways to strengthen volunteerism in Germany's Deutsche Post DHL (Gupta 2011); and water conservation appeals in Thailand tourism resorts (Morgan and Chompreeda 2015). Coupling CSR research with the research on sustainability-related global supply chains (see Allen 2016) in developing countries provides us with a way to look at how various power dynamics influence how CSR is operationalized around environmental and social issues. CSR discourses often claim to be 'doing good to do good', particularly in relation to delivering aid and development in so-called 'developing' countries, when that may not indeed be the case (Brei and Böhm 2013).

\section{Communication, CSR, and sustainability}

Researchers and practitioners need to think more broadly about the role of communication. Given the challenges associated with climate change, effective communication is absolutely essential for the purpose of mobilization; achieving buy-in and agreeing through consensus over priorities. Hence, a measure of "consensus and synergy is required across the board; from the board room to the boiler room; and from the federal government to municipal courts" (Okereke et al. 2012, p. 26). Communication is always present "when sustainability-related issues are conceived, defined, discussed, planned, initiated within and between organizations, modified, and, perhaps, terminated... and when various stakeholders encounter and react to the initiatives," (Allen 2016, p. 25). Communication is pragmatic when it educates, alerts, persuades and helps people enact sustainability initiatives within and between organizations (Cox 2013). Communication is constitutive as it orients people to consider a particular perspective, evokes certain values and not others, and creates referents for our attention and understanding. And, communication occurs at the intrapersonal, interpersonal, group, organizational, interorganizational, and macro environmental level. Theories and research exists to guide communicators at each level in creating CSR or sustainability related SMART (i.e., strategic, memorable, accurate, relevant, and trustworthy) messages and disseminating them through an organization, through a supply chain, and within interorganizational collaborations (see Allen 2016). Researchers interested in identifying useful theories surrounding CSR and/or corporate sustainability initiatives and/or potential research topics will find Allen's work particularly helpful.

Communication about CSR and sustainability has generally been narrowly thought of in terms of public relations, marketing, public affairs, and crisis management strategies. Most often communication was seen as a way to improve a corporate actor's reputation and legitimacy. Corporate sustainability communication (CSC) (Signitzer and Prexl 2008) grew out of the reactive public relations efforts of organizations' corporate social reports and environmental communication programs of the 1970s and 1980s when organizations in certain industries (e.g., chemical, oil) faced environmental scandals. Under pressure, they created communication programs which focused mainly on crisis communication and one-way reporting about environmental success stories. In this essay, due to space limitations we do not review research about CSRrelated public relations and marketing efforts designed to minimize corporate crises. Rather our focus is on how communication can be used to change a corporate actor's operations so it becomes more responsive to its key stakeholders in terms of CSR and sustainability issues, used to create more sustainable supply chains, and used to help 
corporate actors become key partners in creating resilient communities.

Increasingly scholars are talking about the idea of corporate social responsiveness versus corporate social responsibility.

Responsiveness requires communication. Responsiveness emphasizes "how organizational processes and structures need to react to the social needs and values of a wide range of individuals and groups who have an interest in the organization ... Responsiveness concerns the relative permeability of the organization's boundaries and its willingness and ability to anticipate and adjust to society's changing character, needs, and values. In this way responsive organizations are able to be more socially responsible by virtue of their willingness to hear and respond to social needs, standards, and values" (Seeger and Hipfel 2007, p. 157). Responsiveness is an excellent goal, but, given the range of stakeholders who hold a corporate actor accountable (see Allen 2016), to whom should the corporate actor respond in addition to their stockholders? Given the anticipated threats associated with climate change and the multiple voices raised in Paris in December, 2015 at COP21, responsiveness is of critical importance at this time in human history.

Researchers should investigate the responsiveness of corporate actors in terms of CSR and sustainability issues in terms of reporting, stakeholder collaboration to create resilient communities and sustainable supply chains, and corporate activism in helping to change industry norms. Researchers then need to communicate their findings in other outlets in addition to scholarly journals - outlets that reach the business community and stakeholder groups interested in an organization's CSR or sustainability-related initiatives.

One commonly used communication channel past researchers have investigated CSR reports and, more recently, sustainability reports. Scholars have traced the evolution (e.g., Bowers 2010; Maharaj and Herremans 2008) and content of both types of reports (e.g., Morali and Searcy 2013; Tate et al. 2010). Social reports published in the 1970s and 1980s were often advertising instruments lacking honesty, transparency, significant quantitative data, explanations for trends, negative news, or proposed future actions to improve negative results. They largely occurred in response to public pressure following an environmental disaster and stressed regulatory compliance. By the end of the 1970s, although many companies stopped publishing such information, some were successful in their framing efforts (Allen 2016). However, with a renewed interest in gaining legitimacy and signaling their organization's commitment to corporate sustainability, corporate actors located across the globe are publishing more uniform reports often using the Global Reporting Initiative (GRI) comprehensive sustainability reporting framework for measuring and reporting sustainability-related impacts and performance. In their 2011/2012 annual report, GRI summarized a study showing that $95 \%$ of the world's 250 biggest companies disclosed sustainability performance information in 2011, and $80 \%$ of those used the GRI guidelines.

The process of gathering data for and writing sustainability reports can benefit internal and external stakeholders. These reports offer a mechanism to present a company's values and governance model, and show how company strategy reflects its commitment to CSR and/ or sustainability. Going through the process of report writing can help companies set and measure goals, understand the social and environmental impacts of their actions, and communicate about economic, environmental, social, and governance performance. Senior decision makers can use the report's information to shape organizational strategy and policies, and improve performance. However, the evidence suggests that such reports are rarely read across an organization and/or integrated into its key operations (e.g., Mitchell et al. 2012). Moving forward, we need fewer content analytic studies of CSR or sustainability report content and more studies investigating how corporate decision makers can use the report's content to drive true CSR or sustainability-related changes throughout their organizations. Rather than simple descriptive studies, more action oriented predictive models and theory development efforts are needed.

Earlier we reviewed arguments talking about the weakening role of government and the strengthening role of corporate actors in shaping our individual and community experiences. Moving forward in the face of impending climate change challenges, it is important that governments, corporate actors, and communities collaborate. Collaboration requires entities to develop and use effective communication skills and processes.

Determining the meaning of sustainability is a process involving all kinds of stakeholders in many contexts, i.e. people who may not agree with one another. In dealing with conflicts about how to organize, consume and produce in responsible ways, learning does not take place in a vacuum but rather in rich social contexts with innumerable vantage points, interests, values, power positions, beliefs, existential needs, and inequities (Wals and Schwarzin 2012, p. 13).

One of the most powerful tools we possess is our ability to collaborate as we problem solve, plan, implement, assess, and redesign in an ongoing process. Collaborative efforts have grown along with our knowledge of the challenges we face. Interorganizational collaboration efforts cross governments, scientific disciplines, geographic boundaries, and communities, and build on the strengths of various 
stakeholders working together (i.e., businesses, governments, NGOs, communities) to plan and implement interventions and responses. Communication is key to a successful collaboration and multiple useful communication theories and research studies exist in this area (see Allen 2016). However, future research is needed on how successful cross-sector communication can lead to the creation of more resilient communities and more sustainable supply chains.

Future researchers might follow the lead of Uysal (2014) who investigated how shareholder activism can be a driver for positive change in corporate CSR behaviors. Activism is a form of persuasive, and often public, communication. Investors increasingly use ownership rights to influence a corporation's CSR practices and policies. Socially responsible investing efforts integrate social, environmental, and economic responsibilities into investment processes. Such efforts have been present in the financial world in recent years, however, shareholder activism has received very limited scholarly attention in the field of communication. Strategic communication scholars note the need for more theory development and comprehensive empirical investigations into these efforts. It is important to study the impact and the processes associated with initiatives (e.g., the Carbon Disclosure Project) aimed at enlisting the investor community in helping change industry norms related to CSR and sustainability. Yet shareholder activism is not the only form of activism worthy of study. Future research is needed into how centrally located organizations within their industries' institutional field can shape the normative discourse within their industry toward more sustainable or socially responsible actions (Allen 2016). For example, the 43 CEOs (Open letter 2015) referred to at the beginning of this article are engaging in sustainability related corporate advocacy. They write that the private sector has a responsibility to actively engage in global efforts to reduce GHG emissions, and help lead the global transition to a low-carbon, climate-resilient economy. They hope to "catalyze and aggregate action and initiatives from companies from all industry sectors-towards delivering concrete climate solutions and innovations in their practices, operations and policies." They support clear and consistent policies and robust monitoring, reporting and verification, believing such actions will stimulate innovation and collaborative solutions.

The creation of the International Journal of Corporate Social Responsibility gives researchers representing every continent a valuable new forum for publishing scholarship that engages around the key words in the term corporate social responsibility, that addresses issues previously largely unaddressed (e.g., the role of communication in socially responsible investing), and that addresses global climate change challenges. Moving forward it is important to remember corporate actors, communities, governments, and individuals are all on a shared journey into a world forecast to undergo dramatic climate changes. Many are already committed to changing the path. And the journey is only possible through communication which employs SMART messaging.

\section{Competing interests}

The authors declare that they have no competing interests.

\section{Authors' contributions}

The authors' relative contribution is reflected in the authorship order. Both authors read and approved the final manuscript.

\section{Author details}

${ }^{1}$ Department of Communication, University of Arkansas, 434 Kimpel Hall, Fayetteville, AR 72701, USA. Environmental Dynamics Department, University of Arkansas, Ozark Hall, Fayetteville, AR 72701, USA.

Received: 12 March 2016 Accepted: 27 April 2016

Published: 5 July 2016

\section{References}

Allen, M. W. (2016). Strategic communication for sustainable organizations: theory and practice. New York: Springer Publishing Company.

American Heritage Dictionary ( $2^{\text {nd }}$ college ed.). (1982). Houghton Mifflin, Boston. BICEP. (2013). Tackling climate change is one of America's greatest economic opportunities of the 21st century. Retrieved June 25, 2013 from http://www. ceres.org/bicep/climate-declaration.

Blackburn, W. R. (2007). The sustainability handbook: the complete management guide to achieving social, economic and environmental responsibility. London: Earthscan.

Bowers, T. (2010). From image to economic value: a genre analysis of sustainability reporting. Corporate Communications: An International Journal, 15, 249-62. http://dx.doi.org/10.1108/13563281011068113.

Brei, V., \& Böhm, S. (2013). 'I L =10L for Africa': Corporate social responsibility and the transformation of bottled water into a 'consumer activist' commodity. Discourse and Society, 0, 1-29. doi:10.1177/0957926513503536.

Buchholtz, A. K., \& Carroll, A. B. (2008). Business and society: ethics and stakeholder management (7th ed.). Mason: Southwestern Cengage Learning.

Carroll, A. B. (1991). The pyramid of corporate social responsibility: toward the moral management of organizational stakeholders-balancing economic, legal, and social responsibilities. Business Horizons, 34, 39-48. http://dx.doi. org/10.1016/0007-6813(91)90005-G.

Chaudhri, V., \& Wang, J. (2007). Communicating corporate social responsibility on the internet: a case study of the top 100 information technology companies in India. Management Communication Quarterly, 21, 232-47. doi:10.1177/ 0893318907308746.

Chavarria, M. P. (2007). Corporate social responsibility in Mexico: an approximation from the point of view of communication. In S. May, G. Cheney, \& J. Roper (Eds.), The debate over corporate social responsibility (pp. 135-54). New York: Oxford University Press.

Cheney, G., Roper, J., \& May, S. (2007). Overview. In S. May, G. Cheney, \& J. Roper (Eds.), The debate over corporate social responsibility (pp. 3-12). New York: Oxford University Press.

Cox, R. (2013). Environmental communication and the public sphere (3rd ed.). Washington: Sage.

Craig, C.A. (2016). Energy consumption, energy efficiency, and consumer perceptions: a case study for the Southeast United States. Applied Energy. in press.

Department of Defense. (2014). Climate change assessment roadmap. Retrieved January 3, 2016 from http://www.dtic.mil/dtic/tr/fulltext/u2/a610110.pdf.

Dhanesh, G. S. (2015). Why corporate social responsibility? An analysis of drivers of CSR in India. Management Communication Quarterly, 29, 114-29. doi:10. 1177/0893318914545496. 
Eisenstadter, D. (2015). Episcopal Church votes to divest from fossil fuel holdings. Retrieved January 3, 2016 from http://www.gazettenet.com/home/1761441995/episcopal-church-votes-to-divest-from-fossil-fuel-holdings.

Elkington, J. (1999). Cannibals with forks: the triple bottom line of 21st century business. Gabriola Island: New Society Publishers.

Francis. (2014). Laudato si' - On care for our common home [Encyclical letter]. Retrieved from Vatican website http://w2.vatican.va/content/francesco/en/ encyclicals/documents/papa-francesco_20150524_enciclica-laudato-si.html.

Goldenberg, S. (2015). Exxon knew of climate change in 1983, email says - but it funded deniers for 27 more years. The Guardian. Retrieved December 29, 2015 from http://www.theguardian.com/environment/2015/jul/08/exxon-climatechange-1981-climate-denier-funding.

Grant, D., Hardy, C., Oswick, C., \& Putnam, L. L. (2004). Introduction: Organizational discourse: exploring the field. In D. Grant, C. Hardy, C. Oswick, \& L. L. Putnam (Eds.), The Sage handbook of organizational discourse (pp. 1-36). Thousand Oaks: Sage.

Gupta, A. (2011). Strengthening the spirit of volunteerism at Deutsche Post DHL. Strategic Communication Management, 15, 24-7. Retrieved from https://www. melcrum.com/sites/default/files/scm15-9-for\%20web.pdf

Heede, R. (2014). Tracing anthropogenic carbon dioxide and methane emissions to fossil fuel and cement producers, 1854-2010. Climate Change, 122, 229-41. http://dx.doi.org/10.1007/s10584-013-0986-y.

Ingram, K., Dow, K., Carter, L., \& Anderson, J. (2013). Climate of the Southeast United States: variability, change, impacts, and vulnerability. Washington DC: Island Press.

IPCC. (2013). Climate Change 2013: The Physical Science Basis. Contribution of Working Group I to the Fifth Assessment Report of the Intergovernmental Panel on Climate Change. In: T.F. Stocker, D. Qin, G.-K. Plattner, M. Tignor, S.K. Allen, J. Boschung, A. Nauels, Y. Xia, V. Bex, P.M. Midgley (Eds.). Cambridge University Press, Cambridge and New York. doi:10.1017/CBO9781107415324.

IPCC (2014). Climate Change 2014: Mitigation of climate change. Contribution of Working Group III to the Fifth Assessment Report of the Intergovernmental Panel on Climate Change. In: O. Edenhofer, R. Pichs-Madruga, Y. Sokona, E. Farahani, S. Kadner, K. Seyboth, A. Adler, I. Baum, S. Brunner, P. Eickemeier, B. Kriemann, J. Savolainen, S. Schlömer, C. von Stechow, T. Zwickel, J.C. Minx (Eds.). Cambridge University Press, Cambridge and New York. Retrieved at http://www.ipcc.ch/report/ar5/wg1/.

Lawrence, S. (2007). Toward an accounting for sustainability: a New Zealand view. In S. May, G. Cheney, \& J. Roper (Eds.), The debate over corporate social responsibility (pp. 232-40). New York: Oxford University Press.

Maharaj, R., \& Herremans, I. M. (2008). Shell Canada: over a decade of sustainable development reporting experience. Corporate Governance, 8, 235-47. http:// dx.doi.org/10.1108/14720700810879132.

McFarland, J., Zhou, Y., Clarke, L., Sullivan, P., Colman, J., Jaglom, W. S., \& Creason, J. (2015). Impacts of rising air temperatures and emissions mitigation on electricity demand and supply in the United States: a multi-model comparison. Climate Change, 131, 111-25. http://dx.doi.org/10.1007/s10584-015-1380-8.

Mclntosh, M. (2007). Progressing from corporate social responsibility to brand integrity. In S. May, G. Cheney, \& J. Roper (Eds.), The debate over corporate social responsibility (pp. 45-56). New York: Oxford University Press.

McMillan, J. J. (2007). Why corporate social responsibility: Why now? How? In S. May, G. Cheney, \& J. Roper (Eds.), The debate over corporate social responsibility (pp. 15-29). New York: Oxford University Press.

Mitchell, M., Curtis, A., \& Davidson, P. (2012). Can triple bottom line reporting become a cycle for "double loop" learning and radical change? Accounting, Auditing \& Accountability Journal, 25, 1048-68. http://dx.doi.org/10.1108/ 09513571211250242

Morali, O., \& Searcy, C. (2013). A review of sustainable supply chain management practices in Canada. Journal of Business Ethics, 117, 635-58. http://dx.doi.org/ 10.1007/s10551-012-1539-4.

Morgan, M., \& Chompreeda, K. (2015). The relative effect of message-based appeals to promote water conservation at a tourist resort in the Gulf of Thailand. Environmental Communication, 9, 20-36. doi:10.1080/17524032.2014.917689.

Morsing, M., Midttun, A., \& Pabmas, K. (2007). Corporate social responsibility in Scandinavia: a turn toward the business case? In S. May, G. Cheney, \& J. Roper (Eds.), The debate over corporate social responsibility (pp. 87-104). New York: Oxford University Press.

National Climate Assessment. (2014). Retrieved January 3, 2016 from http:// nca2014.globalchange.gov/.

National Oceanic and Atmospheric Administration. (2015). Billion-dollar weather and climate disasters: Mapping. National Centers for Environmental
Information. Retrieved December 15, 2015 from https://www.ncdc.noaa.gov/ billions/mapping.

Okereke, C., Wittneben, B., \& Bowen, F. (2012). Climate change: challenging business, transforming politics. Business and Society, 51, 7-30. doi:10.1177/ 0007650311427659

Open letter. (2015). Open letter from global CEOs to world leaders urging concrete climate action. Retrieved December 30, 2015 from http://www.dsm.com/ corporate/media/informationcenter-pub/2015/04/2015-04-17-open-letterfrom-global-ceos-to-world-leaders-urging-concrete-climate-action.html.

ÖztÜrk, M. C. (2012). Do corporate social responsibility campaigns really work: case in Turkey. Online Journal of Communication \& Media Technologies, 2, 66-95. Retrieved from http://www.ojcmt.net/articles/21/214.pdf.

Preston, B. L. (2013). Local path dependence of U.S. socioeconomic exposure to climate extremes and the vulnerability commitment. Global Environmental Change, 23, 719-32. doi:10.1016/j.gloenvcha.2013.02.009.

Salzmann, O., lonescu-Somers, A., \& Steger, U. (2005). The business case for corporate sustainability: literature review and research options. European Management Journal, 23, 27-36. doi:10.1016/j.emj.2004.12.007.

Samkin, G., \& Lawrence, S. (2007). Corporate and institutional responses to the challenge of HIV/AIDS: the case of South Africa. In S. May, G. Cheney, \& J. Roper (Eds.), The debate over corporate social responsibility (pp. 279-91). New York: Oxford University Press.

Schmidheiny, S. with the Business Council for Sustainable Development. (1992) Changing course: a global business perspective on development and the environment. MIT Press.

Seeger, M. W., \& Hipfel, S. J. (2007). Legal versus ethical arguments: contexts for corporate social responsibility. In S. May, G. Cheney, \& J. Roper (Eds.), The debate over corporate social responsibility (pp. 155-66). New York: Oxford University Press.

Sethi, S. P. (1979). A conceptual framework for environmental analysis of social issues and evaluation of business response patterns. Academy of Management Review, 4, 63-74. Available at http://www.jstor.org/stable/ 257404.

Shen, L., Ochoa, J. J., Shah, M. N., \& Zhang, X. (2011). The application of urban sustainability indicators - A comparison between various practices. Habitat International, 35, 17-29. doi:10.1016/j.habitatint.2010.03.006.

Shumate, M., \& O'Connor, A. (2010). The symbiotic sustainability model: conceptualizing NGO-corporate alliance communication. Journal of Communication, 60, 577-609.

Signitzer, B., \& Prexl, A. (2008). Corporate sustainability communications: aspects of theory and professionalization. Journal of Public Relations Research, 20, 1-19. doi:10.1080/10627260701726996.

Sørensen, K., \& Brand, H. (2011). Health literacy: a strategic asset for corporate social responsibility in Europe. Journal of Health Communication, 16, 322-7. doi:10.1080/10810730.2011.606072.

Sriramesh, K., Ng, C. W., Ting, S. T., \& Wanyin, L. (2007). Corporate social responsibility and public relations: perspective and practices in Singapore. In S. May, G. Cheney, \& J. Roper (Eds.), The debate over corporate social responsibility (pp. 119-34). New York: Oxford University Press.

Stohl, M., Stohl, C., \& Townsley, N. C. (2007). A new generation of global corporate social responsibility. In S. May, G. Cheney, \& J. Roper (Eds.), The debate over corporate social responsibility (pp. 30-44). New York: Oxford University Press.

Suchman, M. C. (1995). Managing legitimacy: strategic and institutional approaches. Academy of Management Review, 20(3), 571-610. Available at http://www.jstor.org/stable/258788.

Tang, L. (2012). Media discourse of corporate social responsibility in China: a content analysis of newspapers. Asian Journal of Communication, 22, 270-88. doi:10.1080/01292986.2012.662515.

Tang, L., Gallagher, C. C., \& Bie, B. (2015). Corporate social responsibility communication through corporate websites: a comparison of leading corporations in the United States and China. Journal of Business Communication, 52, 205-27. doi:10.1177/2329488414525443.

Tate, W. L., Ellram, L. M., \& Kirchoff, J. F. (2010). Corporate social responsibility: thematic analysis related to supply chain management. Supply Chain Management, 46, 19-44.

The pledge. (2015). Retrieved December 29, 2015 from http://www. parispledgeforaction.org/.

Tucker, M. (1997). Climate change and the insurance industry: the cost of increased risk and the impetus for action. Ecological Economics, 22, 85-96. doi:10.1016/S0921-8009(96)00556-3. 
United Nations Conference on Climate Change. (2015a). More details about the agreement. Retrieved December 27, 2015 from http://www.cop21.gouv.fr/en/ more-details-about-the-agreement/.

United Nations Conference on Climate Change. (2015b). $2^{\circ} \mathrm{C}$ target: Result of State contributions. Retrieved December 27, 2015 from http://www.cop21.gouv.fr/ en/2c-target-result-of-state-contributions/.

United Nations Conference on Climate Change. (2015c). The world talks about the Paris agreement. Retrieved December 27, 2015 from http://www.cop21.gouv. $\mathrm{fr} / \mathrm{en} /$ the-world-talks-about-parisagreement/.

United Nations Environmental Programme. (2013). Climate change. Retrieved January 12, 2014 from http://www.unep.org/climatechange/NewHome/ tabid/794594/Default.aspx

Uysal, N. (2014). The expanded role of investor relations: socially responsible investing, shareholder activism, and organizational legitimacy. International Journal of Strategic Communication, 8, 215-30. doi:10.1080/1553118X.2014. 905478.

Wals, A. E. J., \& Schwarzin, L. (2012). Fostering organizational sustainability through dialogic interaction. The Learning Organization, 19, 11-27.

Wei, Y., \& Fang, Y. (2012). Impacts and adaptation of climate change on urban economic system: a perspective from the urban planning. Applied Mechanics and Materials, 1740177, 2270-7. doi:10.4028/www.scientific.net/AMM.174-177. 2270.

Whelan, G. (2007). Corporate social responsibility in Asia: a confucian context. In S. May, G. Cheney, \& J. Roper (Eds.), The debate over corporate social responsibility (pp. 105-18). New York: Oxford University Press.

White, C., Vanc, A., \& Coman, J. (2011). Corporate social responsibility in transitional countries: public relations as a component of public diplomacy in Romania. International Journal of Strategic Communication, 5, 281-92. doi:10. 1080/1553118X.2010.549815

World Commission on Environment and Development. (1987). Our common future. Oxford: Oxford Univ. Press.

World Resources Institute. (2015). Aqueduct: measuring and mapping water risk. Retrieved December 29, 2015 from http://www.wri.org/our-work/project/ aqueduct.

Yin, J., Feng, J., \& Wang, Y. (2015). Social media and multinational corporations' corporate social responsibility in China: the case of ConocoPhillips oil spill incident. IEEE Transactions on Professional Communication, 58, 135-53. doi:10. 1109/TPC.2015.2433071.

\section{Submit your manuscript to a SpringerOpen ${ }^{\circ}$ journal and benefit from:}

- Convenient online submission

- Rigorous peer review

- Immediate publication on acceptance

- Open access: articles freely available online

- High visibility within the field

Retaining the copyright to your article

Submit your next manuscript at $\boldsymbol{s p r i n g e r o p e n . c o m ~}$ 